\title{
Monitoring of Ketogenic Diet for Carnitine Metabolites by Subcutaneous Microdialysis
}

\author{
ALEXANDRA HACK, VERENA BUSCH, BETTINA PASCHER, RAYMONDE BUSCH, IRIS BIEGER, KLAUS GEMPEL,
} AND FRIEDRICH A. M. BAUMEISTER

\begin{abstract}
Department of Pediatric Neurology [A.H., V.B., B.P., F.A.M.B.], Children's Hospital, Technical University Munich, 80804 Munich, Germany; Institute for Medical Statistics and Epidemiology [R.B.], Technical University Munich, 81675 Munich, Germany; Institute for Clinical Chemistry, Molecular Diagnostics, and Mitochondrial Genetics [I.B., K.G.], Academic Hospital Schwabing, 80804 Munich,
\end{abstract} Germany

\begin{abstract}
The ketogenic diet (KD) provides ketones from the degradation of free fatty acids for energy metabolism. It is a therapeutic option for pharmacoresistant epilepsies. Carnitine is the carrier molecule that transports fatty acids across the mitochondrial membrane for degradation into ketones. The integrity of this transport system is a prerequisite for an adequate ketogenic response. For monitoring of tissue metabolism with $\mathrm{KD}$, we used the sampling method of s.c. microdialysis (MD), which permits minimally invasive, frequent, and extensive metabolic monitoring independent of blood tests. By using this new method, we monitored changes in carnitine metabolism induced by $\mathrm{KD}$, particularly in free carnitine $(\mathrm{C} 0)$, acetylcarnitine $(\mathrm{C} 2)$, and hydroxybutyrylcarnitine $(\mathrm{C} 4 \mathrm{OH})$. Correlation of microdialysate and tissue concentrations for carnitines in vitro was about $85 \%$. Carnitine metabolism was monitored in seven children started on a KD for pharmacoresistant epilepsy after a conventional initial fasting period. Detected metabolic changes consisted of a slight decrease in s.c. $\mathrm{C} 0$ and a marked increase in $\mathrm{C} 2 / \mathrm{CO}$ and $\mathrm{C} 4 \mathrm{OH} / \mathrm{CO}$ levels. The levels of s.c. $\mathrm{C} 4 \mathrm{OH}$ strongly correlate with $\beta$-hydroxybutyrate $(\beta$-OHB) levels in plasma providing an additional parameter for the carnitine reserve of the body and reflect an optimal ketogenic energy supply. Subcutaneous MD allows close and extensive monitoring of metabolism with a KD. (Pediatr Res 60: 93-96, 2006)
\end{abstract}

A high-fat, low-carbohydrate KD has been proven to be efficient for intractable childhood epilepsies (1). The metabolic effects of the KD are comparable to prolonged fasting. Glucose substrates are replaced by $\beta$-OHB, acetoacetate, and free fatty acids. Carnitine plays a major role in the degradation of fatty acids. As a trimethylated amino acid, it facilitates translocation of fatty acids into the mitochondrion and is therefore an essential cofactor in fatty acid oxidation and ketogenesis (2). In mammals, changes in the carnitine pattern in plasma and several tissues have been demonstrated with alterations in nutritional state. Studies in humans have shown a delayed decrease in plasma free carnitine and a rapid increase in long- and particularly short-chain acylcarnitines during fasting or diabetic ketosis (3-5). A study in children

Received November 30, 2005; accepted February 4, 2006.

Correspondence: Friedrich A. M. Baumeister, M.D., Pediatric Neurology, Children's Hospital of the Technical University Munich, Kinderklinik München Schwabing, Kölner Platz 1, 80804 Munich, Germany; e-mail: FAM.Baumeister@1rz.uni-muenchen.de.

DOI: 10.1203/01.pdr.0000219479.95410.79 demonstrated that the changes in acylcarnitines during fat load (ingestion of sunflower oil) are more or less comparable to those during fasting (6). However, studies on the dynamics of carnitine metabolism, in particular $\mathrm{C} 4 \mathrm{OH}$, during initiation of a KD have not been reported so far.

The technique of MD is a potent tool for the study of tissue metabolism. The method is based on the diffusion of substances through a semipermeable dialysis membrane implanted in the tissue of interest. It allows repeated measurement of the concentrations of tissue molecules that have crossed the membrane. Water-soluble analytes with a molecular weight below the exclusion size of the catheter cross the membrane until their concentrations in the extracellular fluid and the microdialysate are equal $(7,8)$. In clinical practice, $\mathrm{MD}$ has been established, especially in neurointensive care for bedside monitoring of glucose, lactate, pyruvate, glycerol, and urea $(9,10)$.

Carnitines measured in the MD fluid reflect unbound carnitine metabolites of the surrounding tissue. $\mathrm{C} 0$ and shortchain acylcarnitines like $\mathrm{C} 2$ and $\mathrm{C} 4 \mathrm{OH}$ predominantly occur in their free form. Acylcarnitines in plasma and interstitium are partially bound to plasma proteins. The rate of protein bound carnitines increases with the length of the bound fatty acid.

So far, MD has not been used for carnitine measurements in human tissues. In our study, we show that MD can be used for the determination of carnitine metabolites in the s.c. tissue. Moreover, this technique permits detailed analysis of changes in the s.c. carnitine pattern with a KD over time.

\section{PATIENTS AND METHODS}

The MD device used (CMA/Microdialysis AB, Solna, Sweden) is CE certified for the clinical application on the human brain and s.c. tissue. The study was approved by the local ethics committee, and written consent was obtained from the parents.

Patients. Seven pediatric patients have started on the KD for intractable childhood epilepsy. Patient's median age was 2.5 y (range 0.9-10.6 y).

Abbreviations: C0, free carnitine; C2, acetylcarnitine; C4OH, hydroxybutyrylcarnitine; KD, ketogenic diet; MD, microdialysis; RR, relative recovery; $\boldsymbol{\beta}$-OHB, $\beta$-hydroxybutyrate 
Table 1. Relative recovery in vitro for $\mathrm{CO}, \mathrm{C} 2$, and $\mathrm{C} 4 \mathrm{OH}$

\begin{tabular}{ccc}
\hline & RR (mean $\pm \mathrm{SD}), \%$ & $\begin{array}{c}\text { Tested substance } \\
\text { concentrations, } \\
\text { range }(\mu \mathrm{mol} / \mathrm{L})\end{array}$ \\
\hline $\mathrm{C} 0$ & $86 \pm 7$ & $5-174$ \\
$\mathrm{C} 2$ & $88 \pm 7$ & $7-65$ \\
$\mathrm{C} 4 \mathrm{OH}$ & $83 \pm 9$ & $0.09-0.43$ \\
\hline
\end{tabular}

The KD consists of long-chain triglycerides at a rate of 4:1 (4 g fat/1 g protein + carbohydrates) and was introduced with an initial fasting period according to a standard protocol $(11,12)$.

Fasting was started at $1900 \mathrm{~h}$ of the day of MD catheter insertion (d 0) and continued for $24 \mathrm{~h} \mathrm{(d} \mathrm{1).} \mathrm{At} 1900 \mathrm{~h}$ of d 1, patients received the first ketogenic meal, consisting of one third of their final caloric requirement. On d 2, the amount of calories was increased to two thirds and divided into four meals. From d 3 on, patients received the full amount of calories in four ketogenic meals per day.

As the risk of metabolic decompensation is especially high during initiation of the KD, we closely monitored the patients, determining glucose, lactate, and pyruvate by s.c. MD. Additionally, every morning on an empty stomach and then every $4 \mathrm{~h} \beta$-OHB, glucose, and gas checks were obtained by capillary blood tests.

Microdialysis. The principles of MD have been described in detail previously (13-15). We used a CMA 70 MD catheter (CMA/Microdialysis AB) with a dialysis membrane length of $20 \mathrm{~mm}$. The molecular exclusion size of the polyamide membrane was $20 \mathrm{kD}$. According to the application in neonates and children $(16,17)$, the MD catheters were inserted under sterile conditions upon transdermal local anesthesia (EMLA, Wedel, Germany) into the s.c. tissue of the lateral thigh (younger children) or the forearm (older children). Intravenous plastic cannulas (Vasofix Braunüle, 18 G; Braun Melsungen, Melsungen, Germany) were used as guides.

The catheter was continuously perfused with a sterile isotone solution ( $\mathrm{NaCl} 0.9 \%$ Braun Melsungen). The low flow rate of $0.3 \mu \mathrm{L} / \mathrm{min}$ was ensured by a battery-driven pump (CMA 106 MD pump, CMA/Microdialysis AB). The dialysate samples were collected in microvials (CMA/Microdialysis AB) in a vial holder fixed at the end of the catheter outlet tube. MD duration ranged from 4 to $7 \mathrm{~d}$ and was performed without any complications. Dialysates were collected every $2 \mathrm{~h}$ and were first analyzed for glucose, lactate, and pyruvate at the bedside in the CMA 600 Microdialysis Analyzer (CMA/Microdialysis $\mathrm{AB})$. The residual dialysates were frozen at $-21^{\circ} \mathrm{C}$ for subsequent carnitine determination.

In vitro determination of the relative recovery rate for carnitines. Concentrations of the substances of interest in the dialysate are proportional to the concentrations in the extracellular fluid, depending on membrane length and texture, flow rate and tissue temperature, expressed in the relative recovery rate $(\mathrm{RR})$ of the MD system: $\mathrm{RR}=$ concentration (dialysate)/concentration (surrounding medium).
The relative recovery in our system was determined in vitro by immersing the catheter in test solutions of diluted or carnitine-supplemented human serum.

By adding $0.9 \% \mathrm{NaCl}$ or carnitine stock solution to human serum, solutions of six different concentrations were obtained. They contained $\mathrm{C} 0$ in the range of 5 to $174 \mu \mathrm{mol} / \mathrm{L}, \mathrm{C} 2$ in the range of 7 to $65 \mu \mathrm{mol} / \mathrm{L}$, and $\mathrm{C} 4 \mathrm{OH}$ in the range of 0.09 to $0.43 \mu \mathrm{mol} / \mathrm{L}$.

To avoid matrix effects of serum proteins and to create tissue fluid conditions, the standard solutions were prepared by ultracentrifugation, using ultracentrifuge tubes (Centrisart ${ }^{\circledR}$, Sartorius AG Göttingen, Germany) with a molecular exclusion size of 20,000 D.

A CMA $70 \mathrm{MD}$ catheter with a membrane length of $20 \mathrm{~mm}$ was then immersed in the ultrafiltrates and stirred at room temperature. MD was performed at the in vivo flow rate of $0.3 \mu \mathrm{L} / \mathrm{min}$ and was equilibrated for at least $4 \mathrm{~h}$ before dialysate collection. $\mathrm{C} 0$ and acylcarnitines in ultrafiltrates and dialysates were quantified, and the ratio of carnitine concentrations in the ultrafiltrates and the dialysates was used to determine the RR of the MD system.

Carnitine determination. $\mathrm{C} 0$ and acylcarnitines were quantified in a Perkin Elmer API 365 tandem mass spectrometer (18). Carnitines in microdialysates and ultrafiltrates were directly determined by mass spectrometry.

Statistical analysis. Statistical analysis was performed using the computer program Statistical Package for Social Science version 11.5 (SPSS Inc, Chicago, IL). Statistical significance was tested by analysis of variance for repeated measurements. Post hoc tests were performed one sided. Using a Bonferroni correction, the significance level was set at $1.7 \%$. Results are expressed as median (range) or mean $( \pm \mathrm{SD})$.

\section{RESULTS}

$\boldsymbol{R} \boldsymbol{R}$ in vitro. The $\mathrm{RR}$ in vitro was determined for the CMA $70 \mathrm{MD}$ catheter at a flow rate of $0.3 \mu \mathrm{L} / \mathrm{min}$. The ratio of carnitine concentrations in the dialysate and in the ultrafiltrate revealed a mean RR of $86 \%$ ( $\pm 7 \%$ ) for $\mathrm{C} 0$, of $88 \%$ ( $\pm 7 \%$ ) for $\mathrm{C} 2$, and of $83 \%$ ( $\pm 9 \%$ ) for $\mathrm{C} 4 \mathrm{OH}$ (Table 1).

Changes in the tissue carnitine pattern. During the initial fasting period $(24 \mathrm{~h}) \beta$-OHB levels increased in peripheral blood from $0.13 \mathrm{mmol} / \mathrm{L}( \pm 0.14 \mathrm{mmol} / \mathrm{L}$ ) to $2.80 \mathrm{mmol} / \mathrm{L}$ ( \pm $1.91 \mathrm{mmol} / \mathrm{L}$ ). After $2 \mathrm{~d}$ of KD (d 3), $\beta$-OHB levels exceeded $5 \mathrm{mmol} / \mathrm{L}$ in all patients.

Subcutaneous C2 levels increased significantly $(p=0.001)$ during the fasting period, from $5.13 \mu \mathrm{mol} / \mathrm{L}(2.39-6.49$ $\mu \mathrm{mol} / \mathrm{L})$ before fasting to $13.13 \mu \mathrm{mol} / \mathrm{L}(5.35-21.1 \mu \mathrm{mol} / \mathrm{L})$ after $24 \mathrm{~h}$ of fasting. $\mathrm{C} 2$ increased continuously with $\mathrm{KD}$ to a concentration of $22.42 \mu \mathrm{mol} / \mathrm{L}(9.13-27.24 \mu \mathrm{mol} / \mathrm{L})$ after 24 $\mathrm{h}$ of ketogenic nutrition and then remained stable (Fig. 1A).
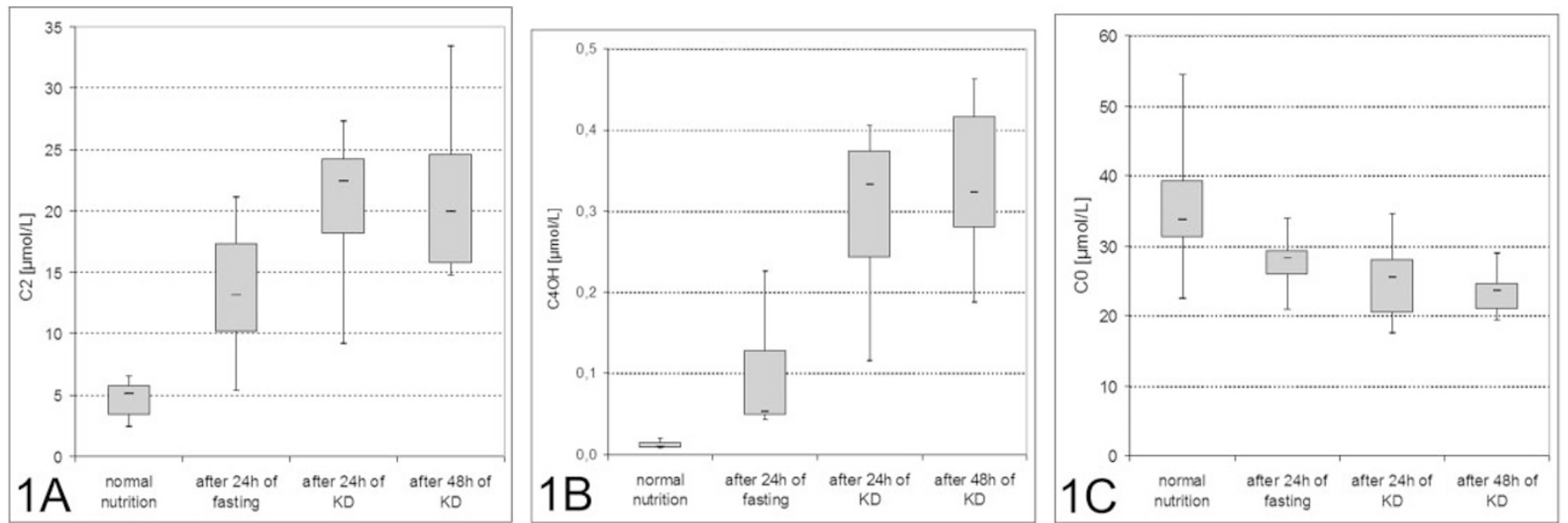

Figure 1. Influence of ketosis on $\mathrm{C} 2(A), \mathrm{C} 4 \mathrm{OH}(B)$, and $\mathrm{C} 0(C)$ in the s.c. tissue. $\mathrm{C} 2(\mu \mathrm{mol} / \mathrm{L})$ and $\mathrm{C} 4 \mathrm{OH}(\mu \mathrm{mol} / \mathrm{L})$ increased significantly with fasting and ketogenic nutrition $\left(\mathrm{p}_{\mathrm{C} 2}=2 \times 10^{-7}, \mathrm{p}_{\mathrm{C} 4 \mathrm{OH}}=1.4 \times 10^{-5}\right)$. s.c. $\mathrm{C} 0(\mu \mathrm{mol} / \mathrm{L})$ decreased slowly with ketosis $(p=0.001)$. Each boxplot is based on 28 values (four values per patient). 


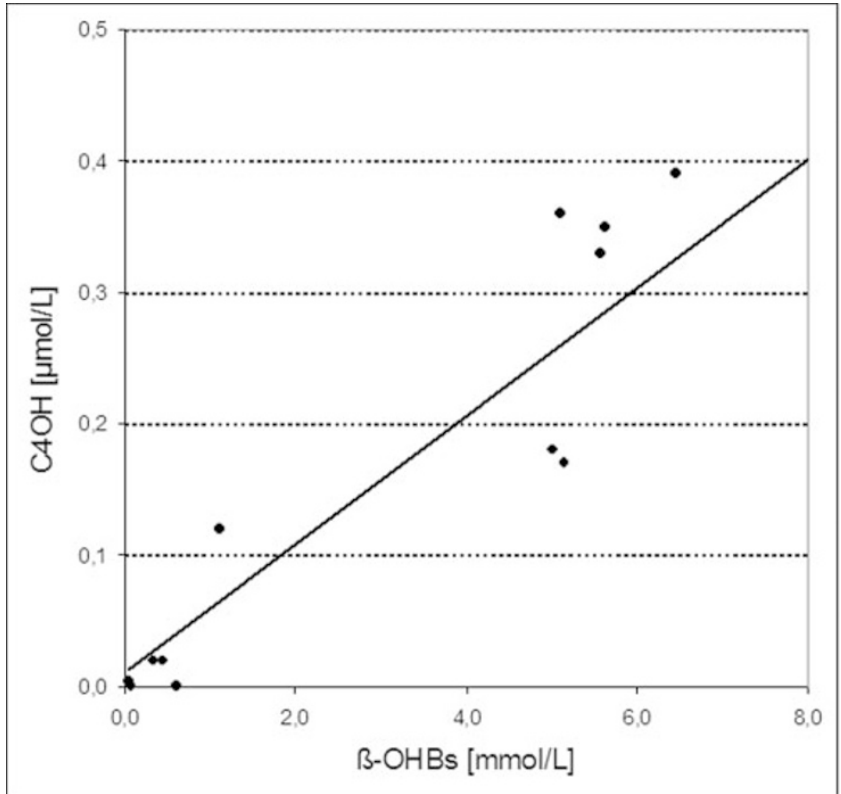

Figure 2. Serum $\beta$-OHB correlates strongly with s.c. $\mathrm{C} 4 \mathrm{OH}$. $\beta$-OHB is plotted against $\mathrm{C} 4 \mathrm{OH}$ in the dialysate $(r=0.91$, including data for seven patients).

Subcutaneous $\mathrm{C} 4 \mathrm{OH}$ levels increased 3.6-fold during $24 \mathrm{~h}$ of fasting from $0.01 \mu \mathrm{mol} / \mathrm{L}(0.01-0.02 \mu \mathrm{mol} / \mathrm{L})$ to 0.05 $\mu \mathrm{mol} / \mathrm{L}(0.04-0.22 \mu \mathrm{mol} / \mathrm{L})(p=0.0025) . \mathrm{C} 4 \mathrm{OH}$ reached $0.33 \mu \mathrm{mol} / \mathrm{L}(0.12-0.41 \mu \mathrm{mol} / \mathrm{L})$ after $24 \mathrm{~h}$ of $\mathrm{KD}$. The level was 23 -fold higher than with normal nutrition and remained stable throughout the second day of KD (Fig. 1B).

$\mathrm{C} 0$ in the s.c. tissue decreased slowly from $33.68 \mu \mathrm{mol} / \mathrm{L}$ $(22.48-54.47 \mu \mathrm{mol} / \mathrm{L})$ to $28.24 \mu \mathrm{mol} / \mathrm{L}(20.89-33.94$ $\mu \mathrm{mol} / \mathrm{L}$ ) after fasting (not significant) and reached 23.62 $\mu \mathrm{mol} / \mathrm{L}(19.31-28.83 \mu \mathrm{mol} / \mathrm{L}$ ) after $2 \mathrm{~d}$ of $\mathrm{KD}$ (significant to the initial value with normal nutrition, $p=0.0045$ ) (Fig. 1C).

We found a strong positive correlation of $\beta$-OHB levels in the blood and $\mathrm{C} 4 \mathrm{OH}$ in the s.c. tissue $(r=0.91$, Fig. 2$)$, and a moderate correlation of $\beta$-OHB in the blood and $\mathrm{C} 2$ in the s.c. tissue $(r=0.7)$.

In accordance with the carnitine changes in the s.c. tissue, we noted a decrease of the serum $\mathrm{C} 0$ as well as an increase in $\mathrm{C} 2$ and $\mathrm{C} 4 \mathrm{OH}$ with increasing ketosis.

\section{DISCUSSION}

We used s.c. MD in children to monitor the KD by changes in the tissue carnitine pattern of $\mathrm{C} 0, \mathrm{C} 2$, and $\mathrm{C} 4 \mathrm{OH}$.

The high relative recovery of the MD system in vitro made s.c. MD suitable for monitoring of tissue carnitine concentrations (15).

Ketosis in children was induced by fasting and maintained with ketogenic nutrition, accompanied by characteristic shifts of carnitine metabolites in the s.c. tissue. Thus, $\mathrm{C} 0$ slowly decreased, whereas $\mathrm{C} 2$ and $\mathrm{C} 4 \mathrm{OH}$ rapidly increased with ketosis.

So far, fasting experiments in animals and humans revealed changes in the blood and urine carnitine pattern similar to our findings. In fasting or diabetic ketosis, a delayed decrease in plasma and urine $\mathrm{C} 0$ and a rapid increase in long- and particularly short-chain acylcarnitines was found and correlated well with increasing plasma ketone levels $(4,5,19)$. Several animal tissues have also been studied for carnitine metabolites under ketotic conditions, such as liver (20-23), skeletal muscle (20-23), heart (22-24), kidney (20,23), and brain (24).

$\mathrm{C} 0$ levels decrease mainly because they are stored in the esterified form. Studies of Hoppel and Genuth (19) revealed an increase in the urinary excretion of acylcarnitines during ketosis, which may lead to a loss of carnitine.

The increase in $\mathrm{C} 2$ reflects an increase in acetyl-coenzyme A $(\mathrm{CoA})$, the final product of $\beta$-oxidation. Via carnitine acetyltransferase in the mitochondria, the acetyl group is transferred to carnitine dependent on the equilibrium constant of the enzyme. By generating $\mathrm{C} 2$ from acetyl-CoA, carnitine may act as an acyl sink to maintain adequate cellular levels of free CoA (25). According to Hoppel and Genuth (19), the $\mathrm{C} 2 /$ carnitine ratio is reflecting the respective $\mathrm{CoA}$ ratio and so may reflect the energy level.

Changes in the $\mathrm{C} 4 \mathrm{OH}$ pattern, especially in combination with carnitines, have not been studied so far. Our MD study revealed the characteristic changes in the s.c. $\mathrm{C} 4 \mathrm{OH}$ pattern, which correlated with increasing levels of $\beta$-OHB in the blood. After $24 \mathrm{~h}$ of fasting, levels had increased fivefold and further increased with KD to a value 23 -fold greater compared with the level before fasting. The s.c. $\mathrm{C} 4 \mathrm{OH}$ was highly correlated with the level of ketone bodies in the blood $(r=$ $0.91)$. Depending on its concentration, $\beta$-OHB may be linked to carnitine in an unspecific enzymatic reaction, as it is described for acetoacetyl-CoA (25). So $\mathrm{C} 4 \mathrm{OH} / \mathrm{CO}$ may also be an indirect marker of energy level. $\mathrm{C} 4 \mathrm{OH}$ might further be a very sensitive parameter for the extent of the ketotic state as it includes a parameter of the body's carnitine reserve as a prerequisite for the effective metabolism of ketone bodies. Indicating a sufficient level of substituted carnitine, $\mathrm{C} 4 \mathrm{OH}$ might be the more accurate parameter for monitoring the state of ketosis than ketone bodies alone.

We conclude that a KD is therapeutic nutrition that causes important changes in patients' metabolism, and close monitoring of patients' energy state is advantageous, especially during initiation of the diet. Subcutaneous MD in combination with spectrometric carnitine determination allows a minimally invasive, close, and extensive monitoring of tissue metabolism.

\section{REFERENCES}

1. Freeman JM, Vining PG, Pillas DJ, Pyzik PL, Casey JC, Kelly MT 1998 The efficacy of the ketogenic diet-1998: a prospective evaluation of intervention in 150 children. Pediatrics 102:1358-1363

2. Fritz IB 1963 Carnitine and its role in fatty acid metabolism. Adv Lipid Res $1: 285-334$

3. Frohlich J, Seccombe DW, Jahn P, Dodek P, Hynie I 1978 Effect on fasting on free and esterified carnitine levels in human serum and urine: correlation of serum levels of free fatty acids and 3-hydroxybutyrate. Metabolism 27:555-561

4. Genuth SM, Hoppel CL 1979 Plasma and urine carnitine in diabetic ketosis. Diabetes 28:1083-1087

5. Hoppel CL, Genuth SM 1980 Carnitine metabolism in normal-weight and obese human subjects during fasting. Am J Physiol 238:E409-E415

6. Costa CC, de Almeida IT, Jakobs C, Poll-The B-T, Duran M 1999 Dynamic changes of plasma acylcarnitine levels induced by fasting and sunflower oil challenge test in children. Pediatr Res 46:440-444

7. Ungerstedt U 1991 Microdialysis-principles and application for studies in animal and man. J Intern Med 230:365-373

8. Hillered L, Persson L 1999 Neurochemical monitoring of the acutely injured human brain. Scand J Clin Lab Invest Suppl 299:9-18 
9. Hillered L, Persson L 1999 Theory and practice of microdialysis-prospect for future clinical use. Acta Neurochir Suppl 75:3-6

10. Persson L, Hillered L 1992 Chemical monitoring of neurosurgical intensive care patients using intracerebral microdialysis. J Neurosurg 76:72-80

11. Freeman JM, Kelly MJ, Freeman JB 1996 The Epilepsy Diet Treatment: An Introduction to the Ketogenic Diet. Demos Publications, New York, pp 1-174

12. Baumeister FA 2004 Anwendung der Ketogenen Diät. In: Baumeister FA (ed) Ketogene Diät-Ernährung als Therapiestrategie-Von den naturwissenschaftlichen Grundlagen zur praktischen Anwendung. Sps Publications, Heilbronn, pp 104-184

13. Arner P, Bolinder J 1991 Microdialysis of adipose tissue. J Intern Med 230:381-386

14. Nakahara D, Ozaki N, Nagatsu T 1993 In vivo microdialysis of neurotransmitters and their metabolites. In: Parvez SH, Naoi M, Nagatsu T, Parvez S (eds) Methods in Neurotransmitter and Neuropeptide Research. Elsevier Science Publishers, Paris, pp 219-248

15. Landolt H, Langemann H 1996 Cerebral microdialysis as a diagnostic tool in acute brain injury. Eur J Anaesthesiol 13:269-278

16. Baumeister FA, Rolinski B, Busch R, Emmrich P 2001 Glucose monitoring with long-term subcutaneous microdialysis in neonates. Pediatrics 108:1187-1192

17. Hack A, Busch V, Gempel K, Baumeister FA 2005 Subcutaneous microdialysis for children — safe biochemical tissue monitoring based on a minimal traumatising no touch insertion technique. Eur J Med Res 10:419-425
18. Gempel K, Kiechl S, Hofmann S, Lochmüller H, Kiechl-Kohlendorfer U, Willeit J, Sperl W, Rettinger A, Bieger I, Pongratz D, Gerbitz KD, Bauer MF 2002 Screening for carnitine palmitoyltransferase II deficiency by tandem mass spectrometry. J Inherit Metab Dis 25:17-27

19. Hoppel CL, Genuth SM 1982 Urinary excretion of acetylcarnitine during human diabetic and fasting ketosis. Am J Physiol 243:E168-E172

20. Brady LJ, Brady PS, Lauri A, Davis AT, Hoppel CL 1986 Carnitine metabolism in lean and obese Zucker rats during starvation. J Nutr 116:668-674

21. Yamaguti K, Kuratsune H, Watanabe Y, Takahashi M, Nakamoto I, Machii T, Jacobsson G, Onoe H, Matsumura K, Valind S, Langstrom B, Kitani T 1996 Acylcarnitine metabolism during fasting and after refeeding. Biochem Biophys Res Commun 225:740-746

22. Brass EP, Hoppel CL 1978 Carnitine metabolism in the fasting rat. J Biol Chem 253:2688-2693

23. Linz DN, Garcia VF, Arya G, Hug G, Tombragel E, Landrigan E, Chuck G, Tsoras M, Ryan M, Ziegler MM 1995 Weanling and adult rats differ in fatty acid and carnitine metabolism during sepsis. J Pediatr Surg 30:959-965

24. Murakami R, Tanaka A, Nakamura H 1997 The effect of starvation on brain carnitine concentration in neonatal rats. J Pediatr Gastroenterol Nutr 25:385-387

25. Bremer J 1983 Carnitine-metabolism and functions. Physiol Rev 63:1420-1480 